\title{
Production and Marketing of Agricultural Crops in Rural Areas of Madhya Pradesh
}

\author{
Rajendra K. Nagesh \\ JLNM College, Sohagpur District Hoshangabad (M.P.)
}

\begin{abstract}
The production and marketing of agricultural crops play an important role of developing countries. It is also accelerating the pace of economic development. It is not only an economic link between the producers and consumers; it maintains a balance between demand and supply. The study examined the production and marketing of agricultural crops through rural markets and the price structure of different crops in rural markets of the Hoshangaabad District. It also highlighted the composition and structure of sellers and traders engaged in the marketing process. Local rural markets are the best option for the marginal and small farmers to dispose of their perishable surplus to get quick returns. Due to the lack of good infrastructural facilities in the study area, most of the farmers prefer local rural markets instead of going to the specialized markets or near-by town area. The average price of the individual crops also varies from market to market due to the various socio-spatial factors. The average participation of crop producer sellers have been recorded high due to the main Mandi is well connected to rural areas, private warehouse available, selling in Madhya Pradesh co-operative society where every $20 \mathrm{~km}$ radius in the study area.
\end{abstract}

Keywords: Production, Marketing, Agricultural crops, Rural markets

DOI: $10.7176 / \mathrm{JMCR} / 68-03$

Publication date:May $31^{\text {st }} 2020$

\section{Introduction}

Crop production is a branch of agriculture that deals with growing crops for use as food and fibre. Livestock production systems can be defined based on feed source, as grassland-based, mixed, and landless (Sere, Steinfeld and Groeneweld, 1995). The major agricultural products can be broadly grouped into foods, fibers, fuels and raw materials. Food classes include cereals, vegetables, fruits, oils, meat, milk, fungi and eggs. The marketing is the performance of all business activities involved in the flow of goods and services from the point of initial agricultural production until they are in the hands of the ultimate consumer (Khols, 1967). Agricultural marketing system in broader terms may be defined as physical and institutional setup to perform all activities involved in the flow of products and services from the point of initial agricultural production until they are in the hands of ultimate consumers. It is through the marketing systems that goods articulate and complete the circle from production to ultimate consumption. Produce change hands from the point of production to the destination of ultimate consumption. The longer the route from production to consumption, the higher becomes the price range of goods. Higher the price range lesser is the profit of the primary producer. Marketing for consumption starts from wholesalers to consumers through retailing. However, the nature of the system will vary according to the type of produce. Goods produced in factories need a different marketing system. In this case, the process of collection is very short as the goods are produced in large quantity at a single point. It needs a chain of agencies, wholesalers, distributors and retailers, etc. In case of agricultural products, the process of collection may need a longer chain. It is because agricultural production is scattered. From farm to wholesalers, there is a wider spatial gap. Most agriculturalists produce a small surplus. The need for providing adequate incentives for increased production is, therefore, very important, and this can be made possible only by streamlining the marketing system (Acharaya \& Agarwal, 2010). Agricultural produce may reach the collection point through farmers themselves, through small traders who act as collecting agents, through these rural markets, through public collecting agencies, etc. It is here that the role of these small but effective trading points is highlighted. These markets, therefore, act as magnates for attracting horizontal and vertical trade. Through horizontal trading, the process of collection starts. The process of collection and distribution of goods is organised through what is termed as marketing system (Shrivastava, 2008). An efficient marketing system ensures higher levels if income for the farmers reducing the number of middlemen or by restricting the cost of marketing services and the malpractices. It guarantees the farmers better prices for farm products and induces them to invest their surpluses in the purchase of modern inputs so that productivity and production may increase. This again results in an increase in the marketed surplus and income of the farmers. If the producer does not have an easily accessible market-output where he can sell his surplus produce, he has little incentive to produce more.

\section{Objectives of investigation}

Taking into consideration the importance of agricultural marketing system in developing economy, the study has been undertaken with the following objectives: 
1 To highlight the price structure of different crops in rural markets.

2. To examine the composition and structure of sellers and traders engaged.

3. To analyse the crops area and production of agriculture crop of Madhya Pradesh

\section{Study area}

Hoshangabad district lies in the central Narmada Valley and on the northern fringe of the Satpura Plateau. It lies between the parallels of $22^{\circ} 15^{\prime}$ and $22^{\circ} 44^{\prime}$ north. In shape, it is an irregular strip elongated along the southern banks of Narmda River. Its greatest length from south-east to north-east is $160 \mathrm{kms}$. Northern boundary of the district is river Narmada. Across this the district of Raisen and Sehore lies (Nagesh, 2017). The district of Betul lies in the south, where as the Harda district faces with the western and south-western boundaries and Narsingpur and Chhindwara districts, close to the north-eastern and south-eastern sides of the district respectively. Pachmarhi is a hill stations in the Satpura range of hills.

\section{Methodology}

The study is entirely based on primary source of data collected though field survey in the year 2009-14 through direct questionnaire method using stratified random sampling technique. The rural market of Bankhedi, Pipariya, Sohagpur, Babai, Hoshangabad, Itarsi, Kesala and Sivani Malva district Hoshangabad (M.P.) has been selected for detailed study and from each rural market and farmers, 50 percent commodity-wise sellers, traders and farmers were interviewed for detailed information regarding transaction, marketing channels, price of different agricultural crops and the composition and structure of sellers and traders. The secondary data were collected from directorate of Land record and settlement, Madhya Pradesh Gwalior and Madhya Pradesh Mandi Board, Bhopal (M.P.)

\section{Observation}

The analyzing the kharif crops acreage and production data for the last five years in Madhya Pradesh, the results were obtained as follows - Paddy acreage was 1603.3 thousand hectares in the year 2009-10 and the production was recorded only 1362.5 thousand tons whereas the year 2011-2012 In 1662.0 thousand hectares, 2227.3 thousand tonnes have been recorded. Paddy crop has been recorded to increase in crop area and production in the coming years. Data shows that paddy cultivation is dependent on water facilities. In previous years this crop was dependent on rainfall, while the effect of government schemes increased rice production and production in the coming years. Crop area and production of Jowar, Maize, Moong and Sesame have been recorded in decreasing order (Table-1) as to why its cultivation is produced at places with less water or less irrigation. The Government of Madhya Pradesh has expanded the irrigation facilities through its schemes, due to which the area under the crops is steadily decreasing. Crop area of soybean where the production was 5453.7 thousand hectares and production was 6427.9 thousand tons in the year 2009-2010, which increased to 6186.4 thousand hectares and the production increased to 8416 thousand tons in the year 2012-2013 (Table-1), production of this crop also on rainfall Based on the year in which the rainfall is continuous for a few days, then the production of this crop decreases as seen in the year 2013-2014. Other crops did not achieve much difference (Table-1). The result of crop area and production of Rabi crops in the last five years at the Madhya Pradesh level is recorded as follows - Wheat acreage was 8872.7 thousand tonnes in 4471.1 thousand hectares in the year 2009-2010, which has now increased to 15522.6 thousand hectares in the year 2013-2014 And production reached 26717 thousand tonnes (Table-1). Similarly, a continuous increase in other crops like gram, pea and sugarcane has been recorded, mainly due to irrigation facilities, availability of electricity. Normal growth in other crops has been recorded (Table-2).

In the rural markets, the prices of commodities are affected by the location of markets, characteristics of the hinterland, nature of demand, supply of goods, durability of commodities, accessibility and transportation cost. Table-2 highlights the average five year retail prices of major agricultural crops, during 2009-14 in the Bankhedi, Pipariya, Sohagpur, Babai, Hoshangabad, Itarsi, Kesala and Sivani Malva rural markets. The average price for Paddy ₹1021, Jowar ₹969, Maize ₹898, Tuar ₹3180, Urda ₹3328, Moong ₹3500, Soyabeen ₹1514, Groundnut 2520, Sesamum ₹3140, Cotton ₹2930, wheat ₹1128, Baraly ₹634, Gram ₹2560, Lentil ₹2130, Mustard ₹1952, Flax ₹ 1520 , and Sugarcane ₹ $140 / 100 \mathrm{~kg}$ respectively. The average price of individual crop also varies from market to market. It is mainly due to the several factors like location of market, nature of supply and demand, road connectivity from cultivation area, characteristics of the market hinterland, transportation cost, seasonal effects, and the socio-economic condition of market participants. Apart from these, there are many more socio-spatial factors, which affect the price structure of these agricultural crops in the rural markets. 
Table-1 Crop area and production of Kharif and Rabi Crop

\begin{tabular}{|c|c|c|c|c|c|c|c|c|c|c|c|c|}
\hline \multirow[t]{2}{*}{ Crops } & \multicolumn{2}{|c|}{ 2009-2010 } & \multicolumn{2}{|c|}{ 2010-2011 } & \multicolumn{2}{|c|}{ 2011-2012 } & \multicolumn{2}{|c|}{ 2012-2013 } & \multicolumn{2}{|c|}{ 2013-2014 } & \multirow{2}{*}{ Total Crop area } & \multirow{2}{*}{$\begin{array}{c}\text { Total } \\
\text { Production }\end{array}$} \\
\hline & Crop area & Production & Crop area & Production & Crop area & Production & Crop area & Production & Crop area & Production & & \\
\hline Paddy & 1603.3 & 1362.5 & 1583.7 & 1773.5 & 1662.0 & 2227.3 & 1801.40 & 3113.00 & 1929.98 & 5360.91 & 8529.37 & 13802.75 \\
\hline Jowar & 497.7 & 594.5 & 467.2 & 598.5 & 428.5 & 599.3 & 306.39 & 601 & 253.14 & 370.97 & 1952.93 & 2764.27 \\
\hline Maize & 848.8 & 1340 & 862.8 & 1287.4 & 823.4 & 1026.6 & 865.4 & 2388.5 & 845.6 & 1487 & 4246 & 7529.5 \\
\hline Tuar & 328.8 & 257.4 & 642.1 & 205.6 & 534.9 & 334.2 & 458.4 & 318.5 & 464.05 & 331.96 & 2428.25 & 1447.66 \\
\hline Urad & 570.3 & 214 & 557.2 & 214.6 & 551.4 & 148.8 & 624 & 256.2 & 585.1 & 218.6 & 2888 & 1052.2 \\
\hline Moong & 75.1 & 25.5 & 85.1 & 31 & 84.6 & 21.3 & 73 & 28.5 & 89.5 & 40.3 & 407.3 & 146.6 \\
\hline Soyabeen & 5453.7 & 6427.9 & 5552.2 & 6776.8 & 5669 & 6280.6 & 6186.4 & 8416 & 6164.4 & 4517.3 & 29025.7 & 32418.6 \\
\hline Groundnut & 210.4 & 254.2 & 203.5 & 305.3 & 213 & 344.6 & 224.5 & 357.5 & 199.2 & 312.4 & 1050.6 & 1574 \\
\hline Sesamum & 320.9 & 140.1 & 360.8 & 178 & 294.9 & 154.9 & 289.4 & 145.1 & 266.93 & 158.08 & 1532.93 & 776.18 \\
\hline Cotton & 630 & 404 & 593.2 & 519.1 & 623.8 & 1029.58 & 606.6 & 1173.28 & 514.2 & 1089.35 & 2967.8 & 4215.31 \\
\hline Wheat & 4471.1 & 8872.7 & 4645.2 & 9227.2 & 14544.4 & 27466 & 16517.9 & 29558 & 15522.6 & 26717 & 55701.2 & 101841 \\
\hline Baraly & 150 & 194.9 & 153 & 197 & 161.6 & 276 & 80.8 & 108.8 & 86.75 & 150.21 & 632.15 & 926.91 \\
\hline Gram & 3013.9 & 3221.3 & 2888.4 & 2265.6 & 3043.7 & 3290.3 & 2722.36 & 3321.09 & 3488.34 & 4187.56 & 15156.7 & 16285.9 \\
\hline Masoor & 520.4 & 272.6 & 698.8 & 201.9 & 587.1 & 215.7 & 511 & 296.9 & 530.1 & 338.33 & 2847.4 & 1325.43 \\
\hline Mustard & 769.9 & 805.2 & 726.9 & 819 & 663.6 & 790 & 704.4 & 962.46 & 762.03 & 752.88 & 3626.83 & 4129.54 \\
\hline Flax & 107 & 48.6 & 94.5 & 33.4 & 91.3 & 47 & 88 & 48.3 & 110.3 & 55 & 491.1 & 232.3 \\
\hline Sugarcane & 18.7 & 60.6 & 24 & 77.2 & 49.7 & 196.8 & 54.1 & 276 & 73.1 & 361.3 & 219.6 & 971.9 \\
\hline
\end{tabular}

Source- directorate of Land record and settlement, Madhya Pradesh Gwalior

Table- 2 Marketing of Kharif and Rabi Crop

\begin{tabular}{|c|c|c|c|c|c|c|c|c|c|c|c|c|}
\hline \multirow[b]{2}{*}{ Crops } & \multicolumn{2}{|c|}{ 2009-2010 } & \multicolumn{2}{|c|}{ 2010-2011 } & \multicolumn{2}{|c|}{$2011-2012$} & \multicolumn{2}{|c|}{ 2012-2013 } & \multicolumn{2}{|c|}{ 2013-2014 } & \multirow{2}{*}{$\begin{array}{c}\text { Average } \\
\text { Producer } \\
\text { Sellers }\end{array}$} & \multirow{2}{*}{$\begin{array}{c}\text { Average } \\
\text { Non } \\
\text { Producer } \\
\text { Sellers }\end{array}$} \\
\hline & $\begin{array}{l}\text { Producer } \\
\text { Sellers }\end{array}$ & $\begin{array}{l}\text { Non } \\
\text { Produce } \\
\text { r Sellers }\end{array}$ & $\begin{array}{l}\text { Producer } \\
\text { Sellers }\end{array}$ & $\begin{array}{c}\text { Non } \\
\text { Producer } \\
\text { Sellers }\end{array}$ & $\begin{array}{c}\text { Producer } \\
\text { Sellers }\end{array}$ & $\begin{array}{c}\text { Non } \\
\text { Producer } \\
\text { Sellers }\end{array}$ & $\begin{array}{l}\text { Producer } \\
\text { Sellers }\end{array}$ & $\begin{array}{c}\text { Non } \\
\text { Producer } \\
\text { Sellers }\end{array}$ & $\begin{array}{l}\text { Producer } \\
\text { Sellers }\end{array}$ & $\begin{array}{c}\text { Non } \\
\text { Producer } \\
\text { Sellers }\end{array}$ & & \\
\hline Paddy & 1050 & 940 & 1000 & 850 & 1080 & 975 & 1250 & 1140 & 1310 & 1200 & 1138 & 1021 \\
\hline Jowar & 840 & 730 & 1030 & 835 & 1110 & 1050 & 1160 & 1080 & 1310 & 1150 & 1090 & 969 \\
\hline Maize & 840 & 720 & 880 & 730 & 980 & 860 & 1175 & 1030 & 1310 & 1150 & 1037 & 898 \\
\hline Tuar & 2300 & 1800 & 3500 & 3200 & 3700 & 3300 & 3850 & 3500 & 4300 & 4100 & 3530 & 3180 \\
\hline Urad & 2520 & 2200 & 3400 & 3100 & 3800 & 3540 & 4300 & 3800 & 4300 & 4000 & 3664 & 3328 \\
\hline Moong & 2760 & 2200 & 3670 & 3250 & 4000 & 3760 & 4400 & 4140 & 4500 & 4150 & 3866 & 3500 \\
\hline Soyabeen & 1390 & 1200 & 1440 & 1220 & 1690 & 1430 & 1850 & 1520 & 2560 & 2200 & 1786 & 1514 \\
\hline Groundnut & 2100 & 1700 & 2300 & 2000 & 2700 & 2200 & 3700 & 3200 & 4000 & 3500 & 2960 & 2520 \\
\hline Sesamum & 2850 & 2280 & 2900 & 2500 & 3400 & 3000 & 4200 & 3820 & 4500 & 4100 & 3570 & 3140 \\
\hline Cotton & 3000 & 2700 & 3000 & 2650 & 3000 & 2700 & 3300 & 2900 & 4000 & 3700 & 3260 & 2930 \\
\hline Wheat & 1100 & 950 & 1170 & 1050 & 1285 & 1150 & 1350 & 1240 & 1400 & 1250 & 1261 & 1128 \\
\hline Baraly & 680 & 550 & 750 & 600 & 780 & 620 & 980 & 850 & 980 & 850 & 834 & 694 \\
\hline Gram & 1740 & 1600 & 1760 & 1620 & 2100 & 1900 & 3000 & 3800 & 3100 & 3880 & 2340 & 2560 \\
\hline Lentil & 1870 & 1700 & 1870 & 1700 & 2250 & 2000 & 2800 & 2500 & 2900 & 2750 & 2338 & 2130 \\
\hline Mustard & 1830 & 1680 & 1830 & 1680 & 1850 & 1700 & 2500 & 2200 & 2800 & 2500 & 2162 & 1952 \\
\hline Flax & 1375 & 1200 & 1575 & 1300 & 1675 & 1400 & 2200 & 1800 & 2300 & 1900 & 1825 & 1520 \\
\hline Sugarcane & 129.84 & 110 & 139.12 & 120 & 145 & 130 & 170 & 150 & 210 & 190 & 158.792 & 140 \\
\hline
\end{tabular}

Source- Questionnaire and Madhya Pradesh Mandi Board, Bhopal

Rural markets are generally a system of direct marketing, which is essentially economical for both producer sellers and consumers. In these markets, there are two types of sellers i.e. producer seller and non-producer seller or village trader. The producer who gets higher price for their commodities realizing middlemen's profit, sell relatively at lower price than the retail price prevailing in near-by town markets (Khan and Khan, 2012). The selling traders, though not getting similar profit as the producer seller, also get handsome profit. It is because he brings the commodities from the villages at lower price (Khan, 1991). Table-2 reveals the participation of producer sellers and non-producer sellers to the crop sellers in the selected rural markets. Out of crop sellers and traders present in the selected market, the non-producer sellers have recorded low participation whereas the crop producer sellers share is high. The average participation of crop producer sellers have been recorded high due to the main Mandi is well connected to rural areas, private warehouse available, selling in Madhya Pradesh co-operative society where every $20 \mathrm{~km}$ radius in the study area. They sell different crops into the rural markets for their livelihood or to supplement their income to sustain their lives.

\section{Conclusion}

Crop area and production of Jowar, Maize, Moong and Sesame have been recorded in decreasing order. Paddy crop has been recorded to increase in crop area and production in the coming years. Wheat acreage was 8872.7 thousand tonnes in 4471.1 thousand hectares in the year 2009-2010, which has now increased to 15522.6 thousand hectares in the year 2013-2014 And production reached 26717 thousand tonnes. The study of agricultural marketing in the study area shows that most of the agricultural surplus is marked within the district itself. Local rural markets are the best option for the marginal and small farmers to dispose of their perishable surplus to get 
quick returns. Due to the lack of transportation and infrastructural facilities, most of the farmers prefer local rural markets instead of going to the specialized markets or near-by town area. Wheat, Soybean and rice are also the principal crops in cultivation and production, but a large proportion of their production is carried out for selling into the specialized markets whereas remaining surplus is saved for selling throughout the year for their future needs. In addition, the prices of agricultural crops are mainly affected by the location of markets, nature of the hinterland, nature of demand and supply, the durability of crops, accessibility and transportation cost. The peasants are more or less independent and work on an individualistic basis. Rural markets are the only place for the farmers to dispose of their surplus when they are in immediate need of money. Among different crop sellers, the average participation of non-producer sellers has been recorded high mainly due to the prevailing unemployment in the study area. They sell different crops into the rural markets for their livelihood or to supplement their income to sustain their lives. The indebtedness of farmers generally compels them to sell their surplus at the distress rate offered by traders who loaned money by Kisan credit card during the pre-harvest period. In general, the marketing of agricultural commodities in the study area is no facing difficulties. Organizational, as well as infrastructural facilities are good.

\section{References}

Abbott, J.C. (1987) Agricultural Marketing Enterprises for the Developing World, Cambridge University Press, Cambridge

Acharaya, S.S. \& Agarwal, N.L. (2010), Agricultural Marketing in India, New Delhi: Oxford \& IBH Publishing Co. Pvt. Ltd.

Baby, K. (2012): "Food security and public distribution system- issues and concerns" Kurukshetra, A Journal of Rural Development, Publication Division, Ministry of I\&B, Government of India, New Delhi, Vol. 58, No. 6, April, p.20

Bajpai, A.K. (2002): A study of regulated agricultural markets in Madhya pradesh with special reference to Bhopal District, Ph.D. Thesis Barkuttullaha Vishvavidhaylaya Bhopal

Banfar, K.N.S., Gauraha, A.K., Choudhary, V.K., Singh, G.N. \& Jain, B.C. (2003). Marketing of soybean in Sehore District of Madhya Pradesh. Indian Journal of Agricultural Marketing, 46(1): 24-26.

Bhalla, G. S. and Gurmail Singh (2001): "Indian Agriculture: Four Decades of Development”, New Delhi: Sage Publications

Bharadwaj, K. (1974) 'Production Conditions in Indian Agriculture', Cambridge: Cambridge University Press.

Dev, S. M. (2012) Small Farmers in India: Challenges and Opportunities, Indira Gandhi Institute of Development Research, Mumbai

Ghosh, M. (2008): "Agricultural Development, Agrarian Structure and Rural Poverty" Economic Reforms \& Indian Economic Development, New Delhi, Bookwell, pp.155-181

Khan, N., Hashmi, S.N.I., Ahmad, A. \& Hoda, M.M. (2006), Livestock Marketing and Diversification of Agriculture, New Delhi: Vista International Publishing House.

Khan, Nizamuddin \& Khan, Muqeet (2012), Marketing of Agricultural Crops in Rural Indian Economy: A Case Study; Journal of Economics and Sustainable Development, 3(2):1-9

Khols, R. L. (1967), Marketing of Agricultural Products (3rd edition), London: Macmillan.

Kothari, C R, (2008) Research Methodology, Second Edition New Age Publications.

Nagesh, R. K. (2017). Madhya Pradesh ke Arthik vikas me krishi utpadakon ka yogdan, unpublished thesis, Barkatullah university, Bhopal

Sere, C.; Steinfeld, H.; Groeneweld, J. (1995). Description of Systems in World Livestock Systems- Current status issues and trends, U.N. Food and Agriculture

Shrivastava, V. K. (2008), Periodic Markets and Agricultural Development, Delhi: Independent Publishing Company. 